\title{
Bacterial contamination of frequently touched objects in a tertiary care hospital of Pokhara, Nepal: how safe are our hands?
}

\author{
Dharm Raj Bhatta ${ }^{*}$, Deependra Hamal, Rajani Shrestha, Supram Hosuru Subramanya, Nisha Baral, \\ Rajesh Kumar Singh, Niranjan Nayak and Shishir Gokhale
}

\begin{abstract}
Background: Objects frequently touched by patients and healthcare workers in hospitals harbor potential pathogens and may act as source of infectious agents. This study aimed to determine the bacterial contamination of common hospital objects frequently touched by patients, visitors and healthcare workers.

Methods: A total of 232 samples were collected from various sites like surface of biometric attendance devices, elevator buttons, door handles, staircase railings, telephone sets and water taps. Isolation, identification and antibiotic susceptibility testing of the isolates was performed by standard microbiological techniques. Biofilm forming ability of the $S$. aureus isolates was tested by a microtitre plate method.

Results: A total of 232 samples were collected and 219 bacterial isolates were recovered from 181 samples. Staphylococcus aureus was the most common bacterial isolate (44/219). Majority of S. aureus isolates were recovered from elevator buttons, biometric attendance devices and door handles. Among the S. aureus isolates, 36.3\% (16/44) were methicillin resistant Staphylococcus aureus (MRSA) while remaining were methicillin sensitive Staphylococcus aureus (MSSA). Out of 44 S. aureus isolates, 12 (29.5\%) were multidrug resistant and 14 (31.8\%) were biofilm producers. The majority of MRSA isolates 62.5\% (10/16) were biofilm producers. Acinetobacter was the most common Gram negative isolate followed by $E$ coli and Pseudomonas species.

Conclusions: High bacterial contamination of frequently touched objects with variety of potential pathogens and normal flora was detected. S. aureus was the most common bacterial isolate. Biofilm forming ability offers additional survival advantage to the organisms on these objects. Present study highlights the need of improved hand hygiene among healthcare workers and regular cleaning/disinfection of sites of frequent public contact.
\end{abstract}

Keywords: Hospital surfaces, Bacterial contamination, Staphylococcus aureus, MRSA, Drug resistance, Cleaning, Disinfection, Biofilm

\section{Background}

Hospital environment, objects/instruments and healthcare workers are likely to get colonized with diverse group of microbial agents. The direct contact with infected and/or colonized patients as well as objects may lead to transmission, resulting into morbidity and mortality $[1,2]$. In the United States, every year approximately two million patients acquire nosocomial infection and at least 90,000 of them die [3, 4]. Nosocomial infections are the fifth leading cause of death in critical-care

\footnotetext{
* Correspondence: ddharma2039@gmail.com

Department of Microbiology, Manipal College of Medical Sciences, Pokhara, Nepal
}

hospitals. The prevalence of hospital acquired infections (HAI) in developing countries is neither recorded nor reported properly due to various reasons [5]. A systemic review has estimated the prevalence of HAIs to be $7.6 \%$ in high income countries and $10.1 \%$ in low and middle income countries [6].

It has been reported that, bacteria can survive for variable duration on surfaces including white coats, stethoscopes, adhesive tape, computer keyboards, elevator buttons, mobile communication devices, and ultrasound transducers $[7,8]$. Risk of transmission is directly proportional to the duration of survival of the bacteria on

(C) The Author(s). 2018 Open Access This article is distributed under the terms of the Creative Commons Attribution 4.0 International License (http://creativecommons.org/licenses/by/4.0/), which permits unrestricted use, distribution, and 
the colonized objects. The colonization and survival depends on geographical and environmental conditions like temperature, humidity, presence of organic matter, ability to form biofilms and the prevalent infection control practices $[9,10]$.

Gram positive and Gram negative bacteria have been reported to survive up to months on dry inanimate surfaces in the hospitals [9]. Nosocomial bacterial pathogens like methicillin resistant Staphylococcus aureus (MRSA), Vancomycin resistant Enterococci (VRE), Pseudomonas spp., Acinetobacter spp. are more stable in the hospital environment. The well-known pathogens like Streptococcus pneumoniae, Streptococcus pyogenes and Haemophilus influenzae are delicate, fastidious and quickly inactivated after excretion from the patients, hence have short survival on inanimate surfaces. The organisms from objects of frequent contact in hospital are likely to get transmitted to healthcare workers, patients and visitors.

This study was planned to investigate the diversity and distribution of bacterial contamination of frequently touched surfaces shared by healthcare workers, patients and visitors. These sites were targeted because these are frequently touched but most neglected from cleaning/ disinfection procedures. Limited data is available regarding bacterial colonization of frequently touched inanimate objects in hospital setting of Nepal. Identification of these sites and bacterial agents may help to reduce transmission of pathogens.

\section{Methods}

This hospital based prospective study was performed at Manipal Teaching Hospital, Pokhara, Nepal, over a period of five months. Manipal Teaching Hospital is a 750 bedded tertiary care hospital having departments of Medicine, Surgery, Pediatrics, Obstetrics and gynaecology, Orthopedics, Otorhinolaryngology, Ophthalmology, Psychiatry, Dermatology Cardiology, Gastroenterology, Urology and Oncology providing care to variety of patients. Approval from the Institutional Ethical Committee (IRC) of Manipal College of Medical Sciences, Pokhara, Nepal, was obtained before commencement of the study. The cleaning and disinfection for floor, table tops, working benches, invasive instruments, Operation Theater (OT) and intensive care units (ICUs) were observed. The floor is wet mopped twice a day in general wards and with detergent solution in ICUs. In addition, automated mopping machine scrubs corridor floor on weekly basis. Table tops and benches are wiped twice a day with $70 \%$ Isopropyl alcohol swabs. Invasive instruments are disinfected with Cidex as per manufacturer's directions. Fumigation of OT, ICUs is performed by fumigator filled with quaternary ammonium compound solution (SOT $125 \mathrm{TM}$ ) on weekly basis. There are no established practices of cleaning/disinfecting surface of biometric attendance devices, elevator buttons, door handles, staircase railings, water taps and telephone sets.

\section{Specimen collection}

A total of 232 samples were collected from various surfaces like biometric finger print devices, elevator buttons, door handles, staircase railings, telephone sets and water taps. Majority of these sites are accessible and commonly used by patients, visitors and healthcare professionals. The most frequently touched surfaces samples were collected from target sites by rubbing and rotating sterile swabs moistened with normal saline. The departments were selected based on the patients load. The most occupied departments such as Medicine, Surgery, Intensive Care Units were included. Length of the swabs used for sampling was approximately $1.5 \mathrm{~cm}$. The available whole surface area of the finger print $(2.5 \mathrm{~cm} \times 1.5 \mathrm{~cm})$, elevator buttons $(2 \mathrm{~cm} \times 2 \mathrm{~cm})$, water tap handles $(3.5 \mathrm{~cm} \times 1 \mathrm{~cm})$ and door handles $(7 \mathrm{~cm} \times 1 \mathrm{~cm})$ was sampled. Handset $(20 \mathrm{~cm} \times 3.5 \mathrm{~cm})$ and number pad $(7 \mathrm{~cm} \times 6 \mathrm{~cm})$ of telephone sets were sampled. Upper part of staircase railing was randomly sampled.

\section{Isolation and identification of bacterial isolates}

Samples were inoculated immediately at the point of collection by rotating and rolling on the surface of $5 \%$ Sheep Blood agar and MacConkey agar plates. Inoculated plates were immediately transported to the laboratory and incubated at $37^{\circ} \mathrm{C}$. Identification of the isolates was performed by standard microbiological techniques such as colony morphology, microscopic features and standard phenotypic characters [11].

\section{Antibiotic susceptibility test}

Antibiotic susceptibility testing of the isolates was performed on Mueller Hinton agar (HI media, Mumbai, India) by Kirby Bauer disc diffusion method [12]. Bacterial isolates resistant to at least one agent in three or more antimicrobial categories were labeled as multidrug resistant (MDR) [13]. Methicillin resistant Staphylococcus aureus (MRSA) were screened by cefoxitin $(30 \mu \mathrm{g})$ disc diffusion method [12]. Extended Spectrum Beta Lactamase (ESBL) production among Gram negative bacilli was performed by standard methods [12].

\section{Biofilm detection}

Biofilm forming ability of the $S$. aureus isolates was tested by crystal violet staining method as described by Christensen et al. [14], with minor modifications. Overnight cultures of bacteria in brain heart infusion broth with $1 \%$ glucose were diluted 1:100 in fresh broth (BHIB) and 200ul of each were added to separate wells of the microtitre plate. Ten different wells containing $200 \mathrm{ul}$ of media (BHIB) for each batch of the test served 
as controls. Microtitre plate was then covered with aluminum foil and incubated at $37{ }^{\circ} \mathrm{C}$. After overnight incubation, the wells were washed four times with sterile phosphate buffer saline, fixed with Boine's fixative (saturated solution of picric acid 75 parts, formaldehyde 25 parts and glacial acetic acid 5 parts) and then stained with Hucker's crystal violet. Excess stain was removed by decanting the plate. The plate was then left at room temperature for $15 \mathrm{~min}$ followed by three washing. After this, $200 \mu \mathrm{l}$ of alcohol: acetone mixture $(80: 20 \mathrm{w} / v)$ was added to each well. $100 \mu \mathrm{l}$ of the mixture from each well was transferred to another microtitre plate and absorbance was recorded at $450 \mathrm{~nm}$. Biofilm producers and non-biofilm producing standard strains of $S$. aureus served as positive and negative controls respectively. The cut off OD (three times the standard deviation above the mean OD) was calculated and used for differentiating biofilm producers and non-biofilm producers. The OD values higher than cut off were considered as biofilm positive.

\section{Results}

Out of 232 samples collected from various sites, bacterial growth was observed in $181(78 \%)$ specimens while remaining 51 (22\%) did not show bacterial growth. A total of 219 bacterial isolates were cultured from 181 sites. Mixed bacterial flora was isolated from various sites. Staphylococcus aureus was the most common isolate cultured from 44 different sites. Details of specimen and bacterial isolates are depicted in Table 1. Majority of S. aureus isolates were from door handles $29.5 \%$ (13/44), elevator buttons 25\% (11/44) and biometric attendance devices 18.1\% (8/44). Among S. aureus isolates, 36.3\% $(16 / 44)$ were MRSA and remaining were MSSA. The antimicrobial resistance pattern of $S$. aureus isolates is shown in Table 2. All the isolates of S. aureus were susceptible to amikacin.

Among Gram negative bacteria, Acinetobacter species, E coli and Pseudomonas species were isolated. Majority
Table 2 Antibiotic resistance pattern of Staphylococcus aureus (MRSA and MSSA) isolates

\begin{tabular}{llll}
\hline Antibiotic & $\begin{array}{l}\text { S. aureus isolates } \\
(n=44) \text { Frequency (\%) }\end{array}$ & $\begin{array}{l}\text { MRSA isolates } \\
(n=16) \\
\text { Frequency (\%) }\end{array}$ & $\begin{array}{l}\text { MSSA isolates } \\
(n=28)\end{array}$ \\
Frequency (\%)
\end{tabular}

MRSA: Methicillin resistant Staphylococcus aureus, MSSA: Methicillin sensitive Staphylococcus aureus

of Acinetobacter species 52.6\% (10/19) and E coli 46.6\% (7/15) were ESBL producers. All the isolates of Acinetobacter species, E coli and Pseudomonas species were susceptible to amikacin and imipenem. The antimicrobial resistance pattern of Gram negative isolates is depicted in Table 3.Out of $44 \mathrm{~S}$. aureus isolates, 12 (29.5\%) were multidrug resistant and $14(31.8 \%)$ were biofilm producers. The majority of MRSA isolates 62.5\% (10/16) were biofilm producers (Table 4).

\section{Discussion}

Microbial population constantly inhabit community and hospital environment. The hospital surfaces are often contaminated with flora excreted by patients, visitors and healthcare workers. The contaminated environmental surfaces are potential reservoirs for spread of microbial agents in hospital as well as community. Persistence of pathogens in hospital environment increases the risk of infection among susceptible host [15]. Microbial population and colonization rate vary with different hospitals of different countries. Study of bacteriological profile of common sites of hand contact would help to

Table 1 Bacteria isolated from environmental surfaces

\begin{tabular}{|c|c|c|c|c|c|c|}
\hline Organisms & $\begin{array}{l}\text { Elevator buttons } \\
(n=48)\end{array}$ & $\begin{array}{l}\text { Biometric attendance } \\
\text { devices }(n=24)\end{array}$ & $\begin{array}{l}\text { Door handles } \\
(n=80)\end{array}$ & $\begin{array}{l}\text { Telephone sets } \\
(n=30)\end{array}$ & $\begin{array}{l}\text { Railing } \\
(n=20)\end{array}$ & $\begin{array}{l}\text { Water taps } \\
(n=30)\end{array}$ \\
\hline S. aureus & $11(22.9 \%)$ & $08(33.3 \%)$ & $13(16.2 \%)$ & $06(20 \%)$ & $03(15 \%)$ & $03(10 \%)$ \\
\hline S. epidermidis & $10(20.8 \%)$ & $06(25 \%)$ & $11(13.7 \%)$ & $04(13.3 \%)$ & $01(5 \%)$ & $02(6.6 \%)$ \\
\hline Enterococcus species & $04(8.3 \%)$ & $05(20.8 \%)$ & $08(10 \%)$ & $06(20 \%)$ & $02(10 \%)$ & 03 (10\%) \\
\hline Diphtheroids & $05(10.4 \%)$ & $04(16.6 \%)$ & $07(8.7 \%)$ & $08(26.6 \%)$ & $04(20 \%)$ & $07(23.3 \%)$ \\
\hline Micrococcus species & $07(14.6 \%)$ & $05(20.8 \%)$ & $08(10 \%)$ & $11(36.6 \%)$ & $02(10 \%)$ & $04(13.3 \%)$ \\
\hline Escherichia coli & $03(6.2 \%)$ & $02(8.3 \%)$ & $04(5 \%)$ & $03(10 \%)$ & $01(5 \%)$ & $02(6.6 \%)$ \\
\hline Pseudomonas species & $02(4.1 \%)$ & $03(12.5 \%)$ & - & - & - & $02(6.6 \%)$ \\
\hline Acinetobacter species & $02(4.1 \%)$ & $03(12.5 \%)$ & $04(5 \%)$ & $05(16.6 \%)$ & $01(5 \%)$ & $04(13.3 \%)$ \\
\hline Total & 44 & 36 & 55 & 43 & 14 & 27 \\
\hline
\end{tabular}


Table 3 Antibiotic resistance pattern of Gram negative isolates

\begin{tabular}{llll}
\hline Antibiotic & $\begin{array}{l}\text { Acinetobacter } \\
\text { species } n=19(\%)\end{array}$ & $\begin{array}{l}\text { Escherichia coli } \\
n=15(\%)\end{array}$ & $\begin{array}{l}\text { Pseudomonas } \\
\text { species } n=07(\%)\end{array}$ \\
\hline ciprofloxacin & $11(57.9)$ & $10(66.6)$ & $04(57.1)$ \\
ceftazidime & $12(63.1)$ & $09(60)$ & $05(71.4)$ \\
cotrimoxazole & $09(47.3)$ & $07(46.6)$ & $04(57.1)$ \\
cefotaxime & $12(63.1)$ & $09(60)$ & $05(71.4)$ \\
gentamicin & $01(5.2)$ & $02(13.3)$ & $02(28.5)$ \\
imipenem & 0 & 0 & 0 \\
amikacin & 0 & 0 & 0 \\
\hline
\end{tabular}

locate the possible reservoirs of bacteria and to apply suitable disinfection techniques.

The bacteriological profile of frequently used objects (Non medical devices) yielded wide variety of organisms ranging from normal flora to potential pathogens like $S$. aureus, Acinetobacter species, E coli and Pseudomonas species. The biometric attendance devices are widely used in hospital as well as community. Microbial colonization of such devices may spread the potential pathogens among unsuspecting users. In our study, $33.3 \%(8 / 24)$ specimens collected from biometric attendance devices showed growth of $S$. aureus of which $25 \%$ $(2 / 8)$ were MRSA. Escherichia coli is commonly associated with community infections, isolation of ESBL producing $E$ coli from these sites indicates possible role in serious nosocomial infections. Acinetobacter species and Pseudomonas species are well known nosocomial pathogens and their presence on biometric devices can lead to spread in the hospital and community. Similar studies have shown the presence of Acinetobacter species, Pseudomonas species and E coli on other inanimate objects of hospital $[16,17]$. Manipal Teaching hospital has more than six hundred healthcare workers who mark attendance twice a day with these devices. Colonization of such devices by potential pathogens like MRSA and ESBL producing Gram negative bacteria indicates the possible spread of these pathogens among the hospital as well as in community population. Most of the healthcare workers before starting their duty and at the end of duty hours mark attendance with biometric devices. At the end of duty hours, healthcare workers wash their hands in their respective departments and then mark attendance on biometric devices. Their fingers may get contaminated with

Table 4 Biofilm production among MRSA and MSSA isolates

\begin{tabular}{llll}
\hline Organisms & \multicolumn{2}{l}{ Biofilm production } & Total \\
\cline { 2 - 3 } & Positive & Negative & \\
\hline MRSA & $10(62.5 \%)$ & $06(37.5 \%)$ & 16 \\
MSSA & $04(14.3 \%)$ & $24(85.7 \%)$ & 28 \\
Total & $14(31.8 \%)$ & $30(68.2 \%)$ & 44 \\
\hline
\end{tabular}

MRSA: Methicillin resistant Staphylococcus aureus, MSSA: Methicillin sensitive Staphylococcus aureus pathogens persisting on the devices. Healthcare workers rarely wash hands after use of biometric attendance devices. This may lead to dissemination of pathogens from hospital into community. Nancy $\mathrm{S}$ et al also reported $33.3 \%$ S. aureus isolation and 70\% MRSA prevalence on biometric device surfaces [18].

Hospital elevator buttons are another frequently touched objects by healthcare workers, patients and visitors. Out of 48 specimens collected from elevator buttons, $22.9 \%$ (11/48) showed growth of $S$. aureus with $36.3 \%(4 / 11)$ MRSA. Sayeed et al reported 75\% contamination of elevator buttons with $S$. aureus which is higher than our findings [19]. Other potential pathogens were Pseudomonas species, Acinetobacter species and $E$ coli. Kandel et al, reported isolation of Staphylococcus species, Pseudomonas species, coliform bacteria from elevator buttons [20]. Healthcare workers including doctors and nurses frequently use elevators. This increases the risk of transmission of these potential pathogens to the patients. Similarly, finger contamination of medical students, visitors and staff by elevator buttons may spread these pathogens in the community as well. Elevator buttons are one of the neglected sites in a hospital, often not cleaned or disinfected and can become potential site for bacterial colonization.

Door handle contamination by potential pathogens has been recorded from the medical ward, surgical ward, ICU and post-operative ward. In a study by Odigie et al., $S$. aureus, Pseudomonas species and $E$ coli were reported as common isolates from door handles [21]. In a recent study, E coli was reported second most common bacterial isolate from door handles [22]. Isolation of $E$ coli from door handles of pediatric units could be threat for serious infections among neonates. In a similar study by Oie $\mathrm{S}$ et al, door handle contamination by $S$. aureus in a University hospital in Japan was $27 \%$ which is comparable with our study (16.2\%) [23]. Saba et al, reported $S$. aureus colonization rate of 39\% (47/120) from door handles, staircase railings and other point of contact in Teaching Hospitals [24]. The MRSA colonization on door handles in our study was $30.7 \%(4 / 13)$ which is higher as compared to above study (17\%). The risk of transmission of pathogens is more as nursing staff, clinicians and visitors frequently touch door handles during visit to wards.

Hospital telephone sets can be important source of nosocomial pathogens in various units. Contamination is likely to occur due to regular hand and ear contact of healthcare workers with almost no attempt at cleaning/ disinfection. The contamination of telephone sets by potential pathogens was observed from Surgery, ICU, Pediatric, Gyanecology and Medicine wards. Culture of telephone sets yielded large number of Acinetobacter species. Isolation of multidrug resistant Acinetobacter 
species and $E$ coli from ICU is alarming. S. aureus colonization rate of telephone sets was $20 \%(6 / 30)$ with $33.3 \%(2 / 6)$ MRSA. In a similar study by Zubair et al., lower, 9\% (4/44) S. aureus contamination was reported [25]. Bacterial contamination of other frequently touched sites like staircase railings pose the risk of transmission especially among the children who fondle railings during hospital visit. Similarly, contamination of water taps (wash room and drinking water) by nosocomial pathogens may lead to contamination of drinking water resulting into gastrointestinal disorders. Presence of potential pathogens on hand operated water taps of washroom increases the possibility of recontamination of hands negating the benefits of hand washing. Above mentioned sites were selected for this study due to frequent and unavoidable contact with these surfaces. These sites are very infrequently cleaned or decontaminated. In most of the teaching hospitals, routine cleaning involves hospital floor, working bench, table tops, nursing stations, dressing trolley etc. However, there is almost no practice of cleaning/ disinfecting sites highlighted in this study. High rate of bacterial contamination in the above mentioned sites reflects poor hand hygiene among the healthcare workers and visitors as transmission occurs mainly through contaminated fingers.

Staphylococcus aureus is well known nosocomial pathogen with its ability to survive in hospital environment for several days [26]. The ability of S. aureus and MRSA to form biofilm on inanimate objects prolongs their survival and spread. Ankit et al. from Nepal, reported $65.7 \%$ clinical isolates of MRSA from pus/wound swabs as biofilm producers, however data related to environmental samples is not available [27]. Majority of MRSA isolates $62.5 \%(10 / 16)$ in our study were biofilm producers which is comparable with above mentioned report. This is alarming as MRSA isolates embedded in biofilm can survive long duration and can become potential source of MRSA associated nosocomial and community infections. Such infections are difficult to treat due to in vivo biofilm formation. Identification of the more frequently contaminated sites and the most commonly identified potential pathogen is important for infection control practices and promotion of new interventions [28].

Study of bacterial contamination of multiple sites of frequent hand contact in a hospital is the strength of our study. Biofilm formation by the most common potential pathogen $S$. aureus is important determinant for their survival and transmission.

This study has some limitations. The molecular characterization of the potential pathogens was not performed. We could not prove the association of pathogens isolated from objects and prevalent nosocomial infections. Biofilm property was studied only for $S$. aureus isolates. The study was conducted in one of the tertiary care hospital and results of the study may not be generalized.

\section{Conclusion}

This is probably the first study in Nepal assessing bacterial contamination of objects most frequently touched but neglected for cleaning/disinfection. Isolation of potential pathogens like MRSA, Acinetobacter species, E coli from common point of contact poses threat of transmission among hospital and community population. Findings of this study are important to emphasize hand hygiene and decontamination of these sites on a regular basis. Availability and use of hand washing/hand sanitizer after contact with biometric system, elevator button or door handles may reduce the possibility of transmission of potential pathogens. Decontamination of the sites with alcohol based disinfectants would reduce the microbial flora from these sites. This process would be convenient as most of these sites have small surface area which can be covered in short period of time. Provision of non-hand touch techniques for doors, taps/faucets could be another way of reducing the transmission.

Acknowledgements

We are thankful to all the staffs of Microbiology Department, Manipal Teaching Hospital, Pokhara, Nepal for their help and support. We would like to thank nursing staff of various units of Manipal Teaching Hospital for their help.

\section{Author's contribution}

DB as a principal investigator designed the study, collected and processed specimen, analyzed data and drafted manuscript. DH, RS, NB, RS and SHS contributed in specimen collection, processing and data analysis. NN and SG contributed in formulating objectives and refining manuscript. All authors have read and approved the final manuscript.

\section{Funding}

No external funding for this study.

Availability of data and materials

Please contact author for data request.

\section{Competing interest}

The authors declare that they have no competing interests.

Ethics approval and consent to participate

Not applicable.

Consent for publication

Not applicable.

\section{Publisher's Note}

Springer Nature remains neutral with regard to jurisdictional claims in published maps and institutional affiliations.

Received: 27 April 2018 Accepted: 19 July 2018

Published online: 06 August 2018

\section{References}

1. Gravel D, Taylor G, Ofner M, Johnston L, Loeb M, Roth VR, et al. A point prevalence survey for healthcare-associated infections within Canadian adult acute-care hospitals. J Hosp Infect. 2007:66:243-8.

2. Dancer SJ. Importance of the environment in meticillin-resistant Staphylococcus aureus acquisition: the case for hospital cleaning. Lancet Infect Dis. 2008;8:101-13. 
3. Stone PW, Braccia D, Larson E. Systematic review of economic analyses of health care-associated infections. Am J Infect Control. 2005;33:501-9.

4. Sydnor ER, Perl TM. Hospital epidemiology and infection control in acutecare settings. Clin Microbiol Rev. 2011;24:141-73.

5. Allegranzi B, Pittet $D$. Preventing infections acquired during health-care delivery. Lancet. 2008:372:1719-20.

6. Ogwang M, Paramatti D, Molteni T, Ochola E, Okello TR, Ortiz Salgado JC, et al. Prevalence of hospital-associated infections can be decreased effectively in developing countries. J Hosp Infect. 2013;84:138-42.

7. Shiferaw T, Beyene G, Kassa T, Sewunet T. Bacterial contamination, Bacterial Profile and Antimicrobial Susceptibility Pattern of Isolates From Stethoscopes at Jimma University Specialized Hospital. Ann Clin Microbiol Antimicrob. 2013;12:39.

8. Schmidt MG, Attaway HH, Sharpe PA, John J, Sepkowitz KA, Morgan A, et al. Sustained reduction of microbial burden on common hospital surfaces through introduction of copper. J Clin Microbiol. 2012;50:2217-23.

9. Kramer A, Schwebke I, Kampf G. How long do nosocomial pathogens persist on inanimate surfaces? A systematic review. BMC Infect Dis. 2006;6:130.

10. Carter MJ. Enterically infecting viruses: Pathogenecity, transmission and significance for food and water borne infections. J Appl Microbiol. 2005;98:1354-80.

11. Cheesbrough M. District laboratory practice in tropical countries. 2nd ed. New York, USA: Cambridge University Press; 2006. p. 62-70.

12. Pa W. Clinical and Laboratory Standards Institute, Performance standards for antimicrobial susceptibility testing, twenty-second informational supplement, CLSI, Document M100 -S27. USA: CLSI; 2017.

13. Magiorakos AP, Srinivasan A, Carey RB, Carmeli Y, Falagas ME, Giske G, et al. Multidrug-resistant, extensively drug-resistant and pandrug-resistant bacteria: an international expert proposal for interim standard definitions for acquired resistance. Clin Microbiol Infect. 2012;18:268-81.

14. Christensen GD, Simpson WA, Younger JJ, Baddour LM, Barrett FF, Malton DM, et al. Adherence of coagulase negative staphylococci to plastic tissue culture plates: a quantitative model to the adherence of staphylococci to medical devices. J Clin Microbiol. 1985;22:996-1006.

15. Mann EE, Manna D, Mettetal MR, May RM, Dannemiller EM, Chung KK, et al. Surface micropattern limits bacterial contamination. Antimicrob Resist Infect Control. 2014:3:28.

16. Uneke CJ, et al. Bacterial contamination of stethoscopes used by health workers: public health implication. J Infect Dev Ctries. 2010;4:436-41.

17. Nirupa S, Gayathri V, Priyadarshani S. A study on bacterial Flora on the finger printing surface of the biometric devices at a tertiary care hospital. IntJ Curr Microbiol App Sci. 2016;5:441-6.

18. Nancy S, Arti J, Navinchandra MK. Evaluation of transient microbial Flora on biometric system as a potential source of infection in tertiary care hospitals. Indian J Microbiol Res. 2016;3:1-4.

19. Khatib SI. A preliminary study of bacterial contamination from elevators. IJSR. 2014;2:10.

20. Christopher EK, Andrew ES, Donald AR. Elevator buttons as unrecognized sources of bacterial colonization in hospitals. Open Medicine. 2014;8:81.

21. Augustine BO, Frederick OE, Paul IO, Sunday O. The role of door handles in the spread of microorganisms of public health consequences in University of Benin Teaching hospital (UBTH), Benin city, Edo state. Pharm Sci Technol. 2017;2:15-21.

22. Frank N. Assessment of bacterial contamination of toilets and bathroom door handles/knobs at Daeyang Luke hospital. Pharma Biol Eval. 2017;4:193-7.

23. Oie S, Hosokawa I, Kamiya A. Contamination of room door handles by methicillin-sensitive/methicillin-resistant Staphylococcus aureus. J Hosp infect. 2002:51:140-3.

24. Courage SSS, Jean KA, Stephen WK. Prevalence and pattern of antibiotic resistance of Staphylococcus aureus isolated from door handles and other points of contact in public hospitals in Ghana. Antimicrob Resist Infect Control. 2017;6:44.

25. Muhammad Z, Sahar I, Aizza Z, Humera J, Hasan E. Frequency of bacterial contamination on telephonic devices in hospital setting. Pak J Med Health Sci. 2016;10:1245-7.

26. Chaibenjawong P, Foster SJ. Desiccation tolerance in Staphylococcus aureus. Arch Microbiol. 2011:193:125-35.

27. Ankit B, Narayan DP, Krishup N, Bibhusan N, Rikesh B, Reena B, et al. Antibiotic resistance and biofilm production among the strains of Staphylococcus aureus isolated from pus/wound swab samples in a tertiary care hospital in Nepal. Ann Clin Microbiol Antimicrob. 2017:16:15.

28. Pittet D, Allegranzi B, Sax H, Dharan S, Pessoa-Silva CL, Donaldson L, et al. Evidence-based model for hand transmission during patient care and the role of improved practices. Lancet Infect Dis. 2006;6:641-52.

Ready to submit your research? Choose BMC and benefit from:

- fast, convenient online submission

- thorough peer review by experienced researchers in your field

- rapid publication on acceptance

- support for research data, including large and complex data types

- gold Open Access which fosters wider collaboration and increased citations

- maximum visibility for your research: over $100 \mathrm{M}$ website views per year

At BMC, research is always in progress.

Learn more biomedcentral.com/submissions 